\title{
Gender Preferences in Classroom Aesthetics
}

\author{
Sybile Cherenfant ${ }^{\mathrm{a}}$
}

\begin{abstract}
Male and female students on the Robert Morris University campus were asked to complete a survey to analyze aesthetics in classrooms. Their answers helped determine what each gender found the most important in his or her learning environment, and whether female students were or were not the most aware of their aesthetic environment. The results demonstrated an insignificant difference between males and females' preferences, but showed that male students were slightly more aware of aesthetics in their classrooms. The conclusion indicated limitations in the study. The research method included only a small amount of students in one university. In addition, the results are limited to college students.
\end{abstract}

Keywords: Classroom Aesthetics, School Facilities

\section{Introduction}

Physical environment, more precisely aesthetics in classrooms, is believed to play a role in students' attitude toward learning. This belief is actually the generator behind the foundation of the Manchester Craftsmen's Guild, an afterschool program for inner-city high school students. Researchers not only consider elements, such as plants, lighting, color and classroom shape as contributors to student's academic performances, but also as what makes the classrooms beautiful. The purpose of this study is to explore which aesthetic element each gender consider important to his or her learning environment.

\section{Literature Review}

\section{The Effect of School Facilities' Conditions on Students}

Several studies support the fact that there is a relationship between the conditions of facilities and students' performances. The conditions of the facilities include their maintenance and the maintenance of the furniture, the lighting and the carefulness to details in decorating them. A school located in a new building with well-maintained desks and chairs can be considered in good condition. Students who attend schools in good conditions tend to perform better. According to Tanner (2000), students who attended schools with "positive outdoor space" scored highly in the Iowa Test of Basic Skills (ITBS). Another study by Berner (1993) shows that students' academic performances increased by 5.46 points when their school facilities' conditions improve from poor to moderate, and increase by 10.9 points when the facilities' conditions improve from moderate to very good. These results help indicate that facilities can be helpful in students' performance in learning.

The founder of Manchester Craftsmen's Guild, William Strickland Jr., said "A person's environment shapes who they are and how they see the world" (2010, para.8). This description of environment includes the schools' facilities, the learning environment, and the relationship with the teachers. The Manchester Craftsmen's Guild is an organization that was designed to help children in the urban areas of Pittsburgh. It is "a multi-disciplined arts and learning center that fosters a sense of belonging, interconnections, and hope within the urban community" (Manchester Craftsmen's Guild, n.d., para.1). The facility of the Manchester Craftsmen's Guild reflects Stickland's idea on the environment.

As it is described in its newsletter, the organization implements light, tune, art, and a staff who is involved in shaping the students for their future (A Better Way Forward, 2009). The idea behind this corporation was to make people feel good about themselves. Strickland stated that "If we treat people like world-class citizens, that's what they will become -- they will dream big and achieve the extraordinary" (Self, 2010, para.1). It is for this reason that these buildings are well maintained and decorated. In the building, there are fresh flowers, fountains, a cafeteria and a kitchen, handmade furniture, and paintings and crafts (Self, 2010). The classrooms are spacious enough for the number of students who attend classes in them with up to date equipment, such as Mac laptops. In addition, there is a mixture of natural and artificial lighting around the building. The building is considered beautiful in the eyes of viewers. This setting is meant to inspire the students to want to succeed.

While there is no evidence that the environment of Manchester Craftsmen's Guild had a direct impact on the students' performances, the results of the work of the faculty and staff have been positive. In 2007, four of the students received scholarship to attend the Art Institute of Pittsburgh, Rochester Institute of Technology, and Dickinson College because of their high quality works (Annual report 20062007 , n.d.). In addition, many of the students who attend the program pursue a college degree. Among the students who joined the program, an average of $75 \%$ to $80 \%$ of them went to College (The "BE" list: Bill Strickland, 2011).

One thing that should be considered is that there is no evidence that specifically show a direct relationship between school conditions and students' academic performance. However, there is often a correlation between the two, the schools' conditions and the students' performances. As Buckley, Schneider and Shang (2004) wrote, "While we do not have the data to identify the specific mechanisms by which compliance is linked to educational outcomes, from existing research, we know that school buildings in poor shape lead to reduced learning. We also know that poorly managed schools lead to poor achievement," (p.5). In addition, there are other factors that play a role in students' performances in school. For instance, one influence on a 
student's performance is his or her upbringing. For example, in a study done by Barry (2005), it was found that students who came from low incomes performed more poorly than students who came from higher income families.

Part of the school facilities "conditions that can relate to students" improving performances are plants. In the Manchester Craftsmen's Guild, William Strickland stated that he had fresh flowers and plants placed inside of the facility to help improve the facility's appearance. This method is actually used by other schools because plants can be contributors to the improvement of students' performances. Daly, Burchett and Torpy (2010) found in their study that "classroom plants consistently led to improved performance in spelling, mathematics and science, i.e., across the curriculum, for possibly a variety of interlinked reasons" (p.7). Plants can help create an agreeable atmosphere for students and can positively impact the students' views. In a study done by Han (2009), it showed that "even six limitedly visible plants in the classroom [in Taiwan] had an immediately significant and positive influence on the students' perceptions of preference, comfort, and friendliness" (p.680).

Another factor of a school's facility that is often associated with students' performances is the lighting in the room. Samani (2011) stated in her study that when classes are equipped with reasonable lighting, which is a mixture of natural and artificial lighting, students are stimulated to learn more, and are showing improved performances. While lighting helps to provide comfort for students, it needs to be at an appropriate level. In the Pollution Prevention Resource Center website, a statement shows that excessive lighting cause extremely high temperature and extremely bright light, which can conflict with the learning environment. This highlights the fact that the characteristic of lighting, not the level of lighting, is important for student learning pattern (Sustainable Design for Schools, n.d.). Appropriate lighting used in schools has helped improve students' achievements. A study by Heschong Mahone Group indicated that students located in classrooms with the most daylight had improved $15 \%$ faster in standardized math tests and $23 \%$ faster in reading tests in comparison to the students in classrooms with the least daylight (Tomasi, n.d.).

Color has also been found to be associated with students' achievements as well. According to Daggett, Cobble, and Gertel (n.d.), "color in the learning environment provides an unthreatening environment that improves visual processing, reduces stress, and challenges brain development through visual stimulation/relationships and pattern seeking" (p.1). This means that the use of color in a classroom can help create a better learning environment. In addition to that, different colors evoke different attitudes from people. For instance, cool colors are suggested for high school students' classrooms because of their capability of encouraging engagement among students, while bright colors should be used for younger students to entice their energetic attitudes (Engelbrecht, 2003). Furthermore, classrooms designed for particular subjects should be painted in colors that help students achieve these particular goals. For instance, the Manchester Craftsmen's Guild's photography studio is painted in light yellow. This color is among the ones suggested by Daggett (n.d.), et. al., for arts classes because of its evocation for creativity.
The shape of a classroom is also related to students' performances. Lippman (n.d.) said that contemporary learning environments complement the idea that learning involves a consultation between people with the supplies from the surroundings. He also stated that contemporary learning environments step away from the typical ones to allow more engagement. In addition, like colors, different shapes of classrooms can cause different outcomes from the students. In a study done by Amadeo and Dyck (2003), teachers found that classrooms shaped like a rectangle or a deep rectangle were least likely to help them use their instructional styles than cross-shaped classrooms, or classes shaped like " $T$ " or "fat-L". There is no ideal shape among the non-rectangle classrooms; the shape depends on the course being taught and the instructor's style of teaching.

Nowadays, classrooms in which students actively participate are strongly suggested. A statement from the Florida State University Instruction handbook (2011) suggests that it is essential for most students to be taught through active learning to connect with their courses. It is for this reason that typical rectangle classrooms would not be the ideal ones, even if the shapes are determined by the courses and the teaching styles. These classrooms usually involve lecture, in which the instructor is the mostly active member. In the University of Delaware website, it is said that "Teacher-centered courses, which emphasize formal lectures and note taking, questions held until the end of class, and little student participation in learning activities, do not seem to promote as much learning as classrooms in which students have a voice" (Positive Classroom Climate, n.d., para.2).

Classroom conditions also affect students indirectly. Classroom conditions can affect teachers and their performance in classrooms. Earthman and Lemasters (2009) stated in their study that "For teachers, the highly stressful work regiment of working with children would mandate that the physical environment of the classroom support and assist them in helping students learn" (p.323). Since teachers use their physical environment to help them teach, the condition of the environment plays a role in how effective they are in teaching.

Earthman and Lemasters (2009) also wrote that weak morale of teachers can affect the learning environment. When a classroom affects a teacher's morale, it eventually affects the students. Earthman and Lemasters (2009) supported this statement by adding that the teachers' morale will play a role in the students' attitudes.

\section{Aesthetics in Classrooms}

Aesthetics in classrooms involve anything that relates to beauty and pleasure to improve students' attitudes toward learning. While there are not many studies done on its effect on students, it is arguable that incorporating aesthetics in classroom design can play a role in students' performances. Ryeden (2009) wrote in his article that "A sense of aesthetics humanizes spaces and stimulates learning, studying and socializing experiences. Being in a beautiful space rather than an ugly space enhances a student's performance" (para.15). The beauty of a classroom can make it more attractive and comfortable for a student to learn. The purpose of an attractive classroom is to bring a homelike atmosphere to students and also to serve as another leaning stimulator. As Terrell (2009) said, decorated classrooms create a good 
atmosphere for students as well as a discernible way for students to learn. There is a lack of study done precisely on understanding the students' perception of aesthetics involving the items that contribute to the beauty of the classrooms.

The influential factors discussed, which are the color, the lighting, the plants, and the shape of a classroom, are contributors to the aesthetics of a classroom. On the website, schoolmentalhealth.org, plants, bulletin boards, banners and warm colors are suggested to create an attractive look for the classrooms (n.d.). As teachers are being meticulous on the factors that impact students' learning, they can also manage to bring aesthetics or, in other word, beauty to the classroom.

In addition to these important factors for student learning environments, other elements, such as classroom furniture, contribute to the aesthetics. Experts usually advised teachers to decorate their classrooms with posters, bulletin boards, banners, and small book shelves. They emphasize the need to have students participate in classroom decorations. Terrell (2009) said in his articles that for middle school students, teachers should encourage them to bring their own posters to decorate their classrooms. This is a way to increase students' awareness of their physical environment.

The whole purpose of adding aesthetics to classrooms is to improve students' awareness and involvement in the class. Terrell (2009) used himself as an example of what he would want in a classroom when he was a student. He has "fond memories of [his]... 9th grade science classroom and how good it made [him]... feel to enter that brightly colored room at one o'clock each school day" (para.1). He showed a positive attitude toward that classroom, which should have certainly helped improve his attitude toward learning.

Creating an atmosphere in which teachers are comfortable also contribute to students' learning. When the classrooms are designed to fit the instructors' teaching styles, they stimulate their enthusiasms for their subjects, which should transmit to the students. Experts even suggest that they personalize the classroom to allow the students to know more about them. Arnold (2009) encouraged teachers to create an all-about-me bulletin board with items that described them, such as family photos and symbols of their favorite sport teams or bands.

\section{Gender differences}

In classrooms, male and female students perform differently from one another. Kovalik (2008) wrote in her article that "they learn differently, they play differently, they fight differently, they see the world differently, they hear differently, and they express their emotions differently. Girls and boys behave differently because their brains are wired differently" (p.2). These elements that differentiate these two genders may impact the way they learn in classrooms.

The sexes differ in some parts of their personalities. Feingold (1994) found in his study that males showed more assertiveness and less anxiety than females, while both genders varied in locus of control. Costa, Terracciano and McCrae (2001) wrote in their article that across cultures, gender differences in personality traits are about the same. There is a slight difference between the two genders in terms of openness to aesthetics. Costa and McCrae (1984) found in their study that women were more opened to aesthetics than men. In addition, women's brains illustrate more reaction to aesthetics than men's brains. Scientists found that women showed more activity in both side of their brains compared to men who showed more activity on the right hand side of their brains (Sample, 2009). Moreover, both genders displayed different preferences in aesthetics. Moss and Gunn (2009) found in their study that female students preferred websites designed by females, while male students preferred the ones designed by males. Meanwhile, both males and females used different themes while designing their websites. For instance, males preferred straight shapes, while females preferred rounded shapes.

Females and males differ cognitively. In 1974, Maccoby and Jacklin wrote that genders differed in their verbal ability, quantitative ability, visual-spatial ability and field articulation. Hyde (1981) did a study on the level of these aforementioned differences, and found an insignificant one. For this reason, although there is a difference in gender cognitive characteristics, it is very slight and often influenced by other factors aside from gender. Although the purpose of this study is to understand the differences of gender preferences in classroom aesthetics, the researches mentioned help predict that the difference will be small. Another expectation is that, based on research and stereotypes, the findings will show that female students are more likely to be aware of aesthetics than male students. The calculations done in this research should help determine whether these two hypotheses are true or not.

\section{Research Method}

The hypotheses for this research predict that there will be insignificant differences between genders, but females will show more awareness of the aesthetics of the classrooms. The research question is: What are the preferences between genders in classroom aesthetics? The different elements of classrooms, which were discussed earlier, are shape, wall decorations, color, lighting, seating arrangements, bulletin boards and furniture. The examination of these preferences provided by each gender through the research method should help determine the ones they are the most aware of.

For the research method, a survey was designed to ask students on their perception of aesthetics in six different classrooms. All the key terms in the questionnaire were based on research done prior to designing the survey. Students were also asked to rate their level of awareness of the elements that are considered part of classroom aesthetics. They were asked to rate, modify, add or take away, and identify in order of importance the elements discussed in the literature review. The questions were designed to encourage the participants to analyze the elements and consequently identify their preferences. However, the questions did not allow them to know that they were being asked on their preferences.

The students were shown pictures of the six classrooms for which they needed to fill out questionnaires of what they thought of them. They were also asked on their general awareness of classroom aesthetics. These specific classrooms were chosen for the survey because they each exhibited components of strong or weak aesthetics based on the elements discussed. Students were asked to pick from a list the elements, such as seating arrangements and color, which they would change, add and take away from the classrooms.

A question was designed to allow the students to pick what best described the six classrooms shown on photos. The terms suggested were chosen based on their association with 
elements of aesthetics. For instance, the term stimulating is associated with colors. Some of the terms were also chosen from another research in which they were suggested for beautiful rooms. Richard $M$. Locasso designed a questionnaire in which he used the words warm, pleasant and appealing as the adjectives to describe the rooms (1992, p.139). These words were used in that survey to get the participants' perceptions of each classroom. To find out whether the participants thought negatively of the appearances of the classrooms, they were asked to rank them from one to six for the adjectives, such as pleasant. For their general thoughts on classroom aesthetics, students were asked about what they first noticed in classrooms and the level of importance of several elements to their learning. In these latter questions, the aesthetic elements were listed with other elements, such as class time and difficulty of class, to find out how important aesthetics is to them compared to other factors.

One hundred students on the Robert Morris University campus were conveniently selected to fill out the 15 to 20 minutes survey. At the end of the survey, they were asked to answer demographic questions that could help gather information on students' preferences based on gender. The students were asked more than one demographic question to assure that they were not aware of the purpose of the survey and to help accurately determine whether the hypotheses were true or not. They were asked demographic questions, such as their year in school, their major, and especially their gender.

\section{Results}

Of the 100 students who participated, 72 filled out the survey completely. Among them were 43 males and 29 females ranging from first to last year in all four schools of the university. Tables 1 and 2 , shown below, display the percentage of the female and male students who would change, add or take away from two of the classrooms that were designed to be very different from each other. One classroom, the Academic Media Center classroom (Fig. 1), is painted in white, has a bulletin board and no wall decorations, and has a traditional seating arrangement. Meanwhile the other classroom, the Honors Lounge (Fig. 2), is yellow, with a non-traditional seating arrangement, wall decorations and a board. Both male and female students supplied the most response to determine what could be modified in both classrooms. There were differences between the percentages of female students who were more likely to modify one item compared to the percentages of male students. For instance, $20.69 \%$ of females would change the Academic Media Center classroom shape compared to $9.90 \%$ among males. One note from the tables is that there was a similar pattern for both male and females students when it came to what elements they selected the most. For instance, the majority of male and female students selected the color of the wall $(46.51 \%$ and $62.07 \%$ respectively) as the element that they would change in the Academic Media Center classroom.

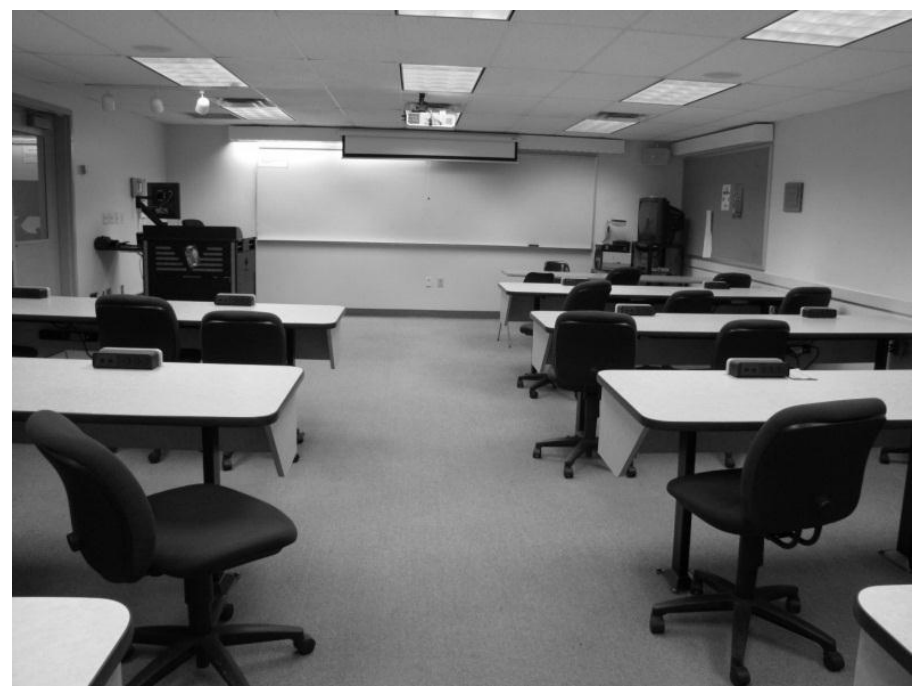

Figure 1: The Academic Media Center classroom

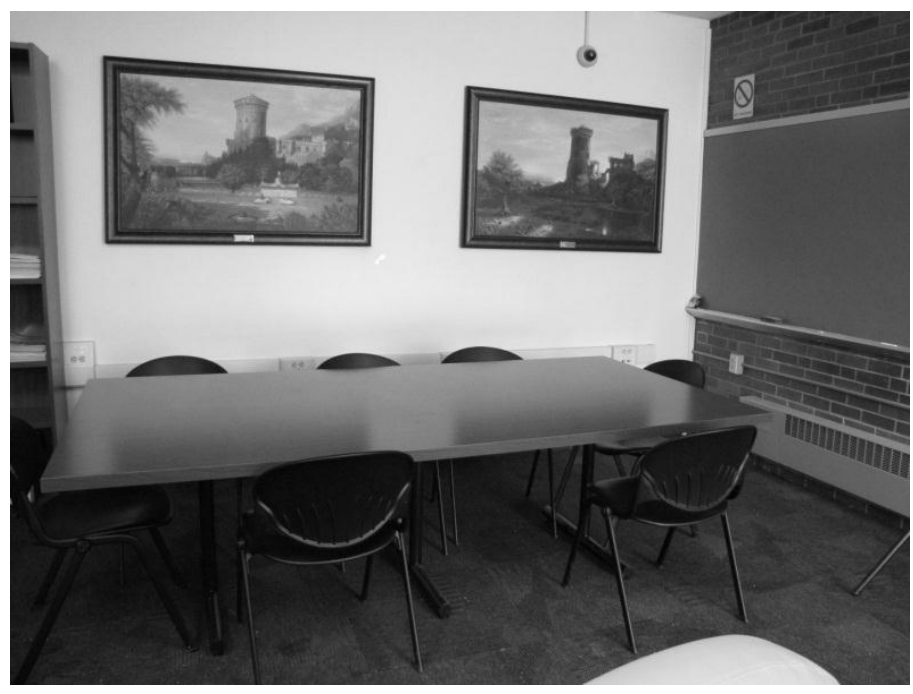

Figure 2: The Honors Lounge 
Table 1: This is a comparison between female and male students. The numbers on the left represent the percentage of female students who would change, add or take away the listed elements from the Academic Media Center classroom. Meanwhile, the numbers on the right represent the percentage of male students.

\begin{tabular}{|c|c|c|c|c|c|c|c|c|}
\hline \multicolumn{9}{|c|}{ Academic Media Center classroom - Female(left) Male (right) } \\
\hline \multicolumn{3}{|c|}{ Change in Classroom } & \multicolumn{3}{|c|}{ Add to classroom } & \multicolumn{3}{|c|}{ Take away from classroom } \\
\hline Wall color & $62.07 \%$ & $46.51 \%$ & Bulletin Board & $10.34 \%$ & $4.65 \%$ & Bulletin boards & $6.90 \%$ & \\
\hline Classroom shape & $20.69 \%$ & $9.30 \%$ & Plants & $24.14 \%$ & $39.53 \%$ & Plants & & \\
\hline Seating arrangement & $34.48 \%$ & $20.93 \%$ & Furniture & $31.03 \%$ & $16.28 \%$ & Furniture & $17.24 \%$ & \\
\hline Furniture & $24.14 \%$ & $13.95 \%$ & Wall Decorations & $75.62 \%$ & $32.56 \%$ & Wall decorations & $6.90 \%$ & $4.65 \%$ \\
\hline Wall decorations & $31.04 \%$ & $30.23 \%$ & Other (Specify) & $3.45 \%$ & $4.65 \%$ & Other (Specify) & & \\
\hline Other (Specify) & $6.90 \%$ & $9.30 \%$ & Nothing & $13.79 \%$ & $32.56 \%$ & Nothing & $79.31 \%$ & $86.05 \%$ \\
\hline Nothing & $13.79 \%$ & $23.26 \%$ & & & & & & \\
\hline
\end{tabular}

Table 2: This is a comparison between female and male students. The numbers on the left represent the percentage of female students who would change, add or take away the listed elements from the Honors Lounge. Meanwhile, the numbers on the right represent the percentage of male students.

\begin{tabular}{|c|c|c|c|c|c|c|c|c|}
\hline \multicolumn{9}{|c|}{ Honors Lounge - Female (left) Male (right) } \\
\hline \multicolumn{3}{|c|}{ Change in Classroom } & \multicolumn{3}{|c|}{ Add to classroom } & \multicolumn{3}{|c|}{ Take away from classroom } \\
\hline Wall color & $17.24 \%$ & $18.60 \%$ & Bulletin Board & $24.14 \%$ & $9.30 \%$ & Bulletin boards & $3.45 \%$ & $4.65 \%$ \\
\hline Seating arrangement & $44.83 \%$ & $41.86 \%$ & Furniture & $17.24 \%$ & $25.58 \%$ & Furniture & $10.34 \%$ & $2.33 \%$ \\
\hline Furniture & $48.28 \%$ & $39.53 \%$ & Wall Decorations & $10.34 \%$ & & Wall decorations & $20.69 \%$ & $11.63 \%$ \\
\hline Other (Specify) & $6.90 \%$ & $4.65 \%$ & Nothing & $34.48 \%$ & $34.88 \%$ & Nothing & $62.07 \%$ & $67.44 \%$ \\
\hline Nothing & $24.14 \%$ & $6.98 \%$ & & & & & & \\
\hline
\end{tabular}

A few questions from the survey were meant to find out which elements were more important to the students in classroom aesthetics. One question requested that the students rate on a scale of one to six the level of importance each element listed in their classrooms. The average ratings of each gender were calculated by finding the means. For this question, both genders rated lighting in the classrooms highly at 5 for females and 5.09 for males. The level of importance of the color of the wall, plants and bulletin boards for both genders was about the same (Wall color=3.35 females, 3.65 males; Plants $=2.86$ females, 2.91 males; Bulletin boards $=3.62$ females, 3.67 females). Female students did find wall decorations and the seating arrangement to be more important than male students (Wall decorations= 4.86 females, 3.44 males; Seating arrangement $=5.83$ females, 4.33 males). Meanwhile, male students considered the furniture and the shape of the classrooms more important than female students (Furniture=5.47 males, 4.28 females; Classroom shape $=5.14$ males, 4.07 females).

In addition to what they found the most important in their learning environment, students were asked to select the elements they first noticed when they walked into a classroom. The majority of both male and female students first noticed the seating arrangement when they walked into a classroom (96.56\% for females and $86.05 \%$ for males). Lighting came in second as the first thing female and male students noticed in classrooms $(51.72 \%$ and $37.21 \%$ respectively). Table 3 displays the percentage of male and female students who noticed each of the elements first.

Both genders showed a fair amount of awareness of the physical appearance of their classroom. However, contrary to the hypothesis, males actually rated their level of awareness slightly higher than the females' at 4.19 in mean compared to 3.66 for females. For this reason, the results supported the first hypothesis, but did not support the second one. The results showed a small difference between the males and females who completed the survey in terms of their preferences in classroom aesthetics. However, the female students are surprisingly less aware of their classroom aesthetics. 
Table 3: This is a comparison between the percentage of male and female students who first noticed each element listed. The percentages of male students are listed above, and the percentages of female students are listed below.

\begin{tabular}{lr}
\hline \multicolumn{2}{c}{ What do you first notice when you walk in a } \\
classroom- Male Students \\
\hline Color & $32.56 \%$ \\
\hline Seating arrangement & $86.05 \%$ \\
\hline Shape of classroom & $27.91 \%$ \\
\hline Wall decorations (posters, banners, etc...) & $16.28 \%$ \\
\hline Plants & $18.60 \%$ \\
\hline Furniture & $30.23 \%$ \\
\hline Lighting & $37.21 \%$ \\
\hline Bulletin board & $4.65 \%$ \\
\hline Temperature & $32.56 \%$ \\
\hline Other (specify) & $4.65 \%$ \\
\hline \multicolumn{1}{c}{ What do you first notice when you walk in a } \\
\hline Color & $48.28 \%$ \\
\hline Seating arrangement & $96.56 \%$ \\
\hline Shape of classroom & $20.69 \%$ \\
\hline Wall decorations (posters, banners, etc...) & $13.79 \%$ \\
\hline Plants & $6.90 \%$ \\
\hline Furniture & $20.69 \%$ \\
\hline Lighting & $51.72 \%$ \\
\hline Bulletin board & $51.72 \%$ \\
\hline Temperature & $3.45 \%$ \\
\hline Other (specify) & \\
\hline
\end{tabular}

\section{Discussion and Conclusion}

Compared to females, males reported that they were more aware of their physical environment. However, as expected, there is a slight difference, but not significant, between both genders in terms of their preferences in their physical learning environment. The participants often showed a similar pattern in the elements they selected when analyzing the classrooms. The majority of males and females mostly ranked the same elements in their level of importance to them. Among these element (color, classroom shape, seating arrangements, wall decorations, bulletin boards, lighting and furniture) students appeared to pay less attention to plants, wall decorations and bulletin boards. These three elements, especially plants, are actually related to students' improvement in academic performances. Meanwhile, both genders often ranked the lighting and the seating arrangement in the classrooms more highly. While certain elements were ranked more highly than others by the participants, there was mostly an insignificant difference in those rankings.

The participants more often chose to change and add to the six classrooms, rather than take away from them. Meanwhile, they mostly picked the color of the wall as an element that they would change in the classrooms, excluding the Honors Lounge, which exhibited components of strong aesthetics the most. The Honors Lounge consists of brick walls with one painted in white. Another classroom, for which students wanted to change its color, consisted of yellow walls, and a fuchsia wall. Compared to the latter classroom, the Honors Lounge contains many wall decorations. This suggests that students may consider a wall, despite its color, more aesthetically pleasing when decorated.

The seating arrangement, the lighting, and the color of the wall are the three aesthetic elements that female students identify as the first thing they notice when they walk into a classroom. Meanwhile, male students first noticed the color of the wall, the seating arrangement, the shape of the classroom, the furniture and the lighting. These elements can be considered what the genders prefer with lighting and seating arrangement being on top of the list for both males and females.

As mentioned in the Literature Review, classrooms should be designed to fit the course material and teacher's style of instructing. For this reason, a "T" shape classroom could be ideally to a teacher or the students, but not to another group. Certain classrooms for creative projects are designed to allow a more interactive setting. For instance, one art classroom would be painted in yellow, would have a seating arrangement in which several desks are placed with group of four to six students, and would have the students' projects displayed as decorations.

This study is certainly in need of expansion. A larger number of participants in a more spread out area, several universities around the country, could help determine whether the results were accurate or not. It is possible that the participants will have different attitudes toward classrooms they are not familiar with. In this research, students were under the impression that they were asked on their thoughts and opinion what needed to be changed in the classrooms in Robert Morris University to improve their learning environment.

At time, several students were confused with a few questions from the survey. For this reason, there is a possibility that they did not answer these questions accurately. Further study on this research will require more comprehensive questions to obtain more accurate answers from the subjects. This could lead to slightly different results. The replication of the research method should involve a survey completed by about the same amount of males as females.

The results are also limited to college male and female students' preferences toward classroom aesthetics. Therefore, to generalize the results, there will need to be students from different grades in high school, middle school and more. There will also need to be more than just a survey. The survey limits the participants from providing more information on their attitudes toward classroom aesthetics. A research method that involves observations and focus groups could also lead to very accurate results.

\section{Acknowledgement}

Sincere thanks goes to advisors Dr. Philip Harold and Dr. Monica VanDieren. 


\section{References}

Amedeo, D., Dyck, J. A. (2003). Activity-enhancing arenas of designs: A case study of the classroom layout. Journal of Architectural and Planning Research, 20(4), pp. 323-343. Retrieved November 30, 2011, from http://japr.homestead.com/files/AMEDEO.pdf

Annual Report 2006-07. (2007). Manchester Bidwell Corporation.

Barry, J. (2005). The Effect of Socio-Economics Status on Academic Achievement. Department of Sociology, Retrieved November 25, 2011 from http://soar.wichita.edu/dspace/bitstream/handle/10057/616/ barry_jennifer.pdf?sequence $=1$

Arnold, F. (2009). Back to school classroom decorating ideas for teachers. Retrieved from Helium Web site: http://www.helium.com/items/1542954-back-to-schooldecorating-ideas-for-teachers

Berner, M. (1993). Building conditions, parental involvement, and student achievement in the District of Columbia Public School System. Urban Education, 28 (1), pp. 6-29. Retrieved November 7. 2001 from Sage Journals.

Buckley, J., Schneider, M. \& Shang, Y. (2004). LAUSD School Facilities and Academic Performance. Retrieved October 26, 2011 from the National Clearinghouse for Educational Facilities. Web site: http://www.edfacilities.org/pubs/LAUSD\%20Report.pdf

Costa, P., McCrae, R. (1984). Personality and vocational interests in an adult sample. Journal of Applied Psychology, 69(3), pp. 390-400. Retrieved November 27, 2011, from EBSCO.

Costa, P., Terracciano, A., \& McCrae, R. (2001). Gender differences in personality traits across cultures: Robust and surprising findings. American Psychological Association, 81(2), pp. 322-331. Retrieved November 27, 2011, from EBSCO.

Daggett, W. R., Cobble, J. E., Gertel, S. J. (2008). Color an optimum learning environment. Retrieved from the International Center for Leadership in Education Web Site: http://www.leadered.com/pdf/Color\%20white\%20paper.pd $\mathrm{f}$

Daly, J., Burchett, M., Torpy, F. (2010). Plants in the classroom can improve student performance. National Interior Plantscape Association. Retrieved October 15, 2011, from

http://www.nipa.asn.au/docs/Research\%20Report\%20Effects\%20of\%20indoor\%20plants\%20on\%20school\%20p erformance\%20(2010)\%20V1.pdf

Earthman, G. L., Lemasters, L. K. (2009). Teacher attitude about classroom conditions. Journal of Educational Administration, 47(3), pp. 323-335. Retrieved October 31, 2011 from http://www.emeraldinsight.com/journals.htm?issn=0957$8234 \&$ volume $=47 \&$ issue $=3 \&$ articleid $=1793197 \&$ show $=$ ht ml\&PHPSESSID $=$ dm904obs7fatv51u4oj04m3d03

Effective Classroom Management. (n.d.). Retrieved October 15, 2011, from the School Mental Health Web site: http://www.schoolmentalhealth.org/Resources/Educ/CAM HPS/Effective\%20Classroom\%20Management.pdf
Engelbrecht, K. (2003). The Impact of color on learning. Perkins \& Will, p.1-6. Retrieved October 20, 2011, from http://www.coe.uga.edu/sdpl/HTML/W305.pdf

Feingold, A. (1994). Gender differences in personality: A meta-analysis. American Psychological Association, 116(3), pp. 429-456. Retrieved November 27, 2011, from EBSCO.

Han, K.T.. Influence of limitedly visible leafy indoor plants on the psychology, behavior, and health of students at a junior high school in Taiwan. (2209). Environment and Behavior, 41(5), pp. 658-692. Retrieved October 15, 2011, from http://eab.sagepub.com/content/41/5/658.full.pdf+html

Hyde, J. (1981). How large are cognitive gender differences? A meta-analysis using ! $\mathrm{w}^{2}$ and d. American Psychological Association, 36(8), pp. 892-901. Retrieved November 27 , 2011, from EBSCO.

Kovalik, S. J. (2008). Gender differences and student engagement. Retrieved November 30, 2011 from the International Center for Leadership and Learning Web site: http://www.leadered.com/pdf/Student $\% 20$ Engagement $\% 20$ and\%20Gender\%20white\%20paper.pdf

Lippman, P. C. (n.d.). The L-Shaped classroom: A pattern for promoting learning. Retrieved November 9, 2011 from the DesignShare Web Site:

http://www.designshare.com/index.php/articles/the-1shaped-classroom/

Locasso, R. M. (1992). Influence of beautiful versus ugly room. In J. L. Nasar (Ed.), Environmental aesthetics: Theory, research, and application (pp.132-142). New York, Ny: Cambridge University Press.

Manchester Bidwell Corporation. (n.d.). Manchester Craftsmen's Guild. Retrieved April 2, 2011 from the Manchester Bidwell Corporation Web Site: http://manchesterbidwell.org/manchester-craftmensguild/index.php

Manchester Bidwell Corporation Newsletter. (2009). A better way forward. Retrieved April 2, 2011 from the Manchester Bidwell Corporation Web Site:

http://www.manchesterbidwell.org/documents/ABetterWay Forward_090309e.pdf

Moss, G. A., Gunn, R. W. (2009). Gender differences in website production and preference aesthetics: preliminary implications for ICT in education and beyond. Behavior and Information Technology, 28(5), pp. 447-460. Retrieved July 27, 2012 from EBSCO.

Positive Classroom Climate. (n.d.). Retrieved from the University of Delaware, Center for Teaching and Learning Web site: http://cte.udel.edu/publications/handbookgraduate-assistants/getting-started/positive-classroomclimate.html

Rydeen, J. E. (2003). Focusing on human factors. Retrieved November 9, 2011 from the American School and University Web site: http://asumag.com/mag/university_focusing_human_factor s/ 
Samani, S. A. (2011). The Influence of light on student's learning performance in learning environments: A knowledge internalization perspective. World Academy of Science, Engineering and Technology 81. Retrieved October 30, 2011 from http://www.waset.org/journals/waset/v81/v81-105.pdf

Sample, I. (2009). Women appreciate beauty better than men, says study: Scientists claim human males only appreciate beautiful images with one side of brain, while females use both. Retrieved July 27, 2012 from The Guardian Web Site: http://www.guardian.co.uk/science/2009/feb/24/womenmen-beauty-study

Self, J. (2010). Author, entrepreneur brings educational vision to Winthrop. McClatchy - Tribune Business News. Retrieved April 2, 2011, from Proquest.

Strickland, W. (2010). Vision inspires. Leadership Excellence, 27(10), p. 15. Retrieved April 15, 2011, from Proquest.

Sustainable Design for Schools. (2001). Retrieved November 2, 2011 from the Pollution Prevention Resource Center Web site: http://www.pprc.org/pubs/schools/design.cfm
Tanner, K. C. (2000). The influence of school architecture on academic achievement. Journal of Educational Administration, 38(4), p. 309-330. Retrieved October 15, 2011 from http://www.emeraldinsight.com/journals.htm?articleid=839 $178 \&$ show $=$ html

Terrell, D. M. (2009). Back to school classroom decorating ideas for teachers. Retrieved April 25, 2012, from the Helium Web site: http://www.helium.com/items/1554425decorated-classrooms-back-to-school-decorationspreschoolers-middle-schools

The Be list: Bill Strickland. (2011). Be Magazine. Retrieved September 30, 2011, from http://www.bemagazine.org/?p=1662.

Instruction at FSU: A guide to teaching and learning practices. (2011). The Florida State University Office of Distance Learning. Retrieved April 25, 2012, from http://ctl.fsu.edu/explore/onlineresources/docs/Chptr1.pdf Tomasi, D. (n.d.). Evidence-based design in schools: Classroom design and academic achievement. Retrieved October 27, 2011 from the TLCD Architecture Web Site: http://www.tlcd.com/documents/2010\%20EvidenceBased\%20Design\%20in\%20Schools.pdf 